\title{
Prostate Cancer Disparities by Race and Ethnicity: From Nucleotide to Neighborhood
}

\author{
Timothy R. Rebbeck \\ Dana Farber Cancer Institute and Harvard T.H. Chan School of Public Health, Boston, Massachusetts 02215 \\ Correspondence: timothy_rebbeck@dfci.harvard.edu
}

Prostate cancer (CaP) incidence, morbidity, and mortality rates vary substantially by race and ethnicity, with African American men experiencing among the highest CaP rates in the world. The causes of these disparities are multifactorial and complex, and likely involve differences in access to screening and treatment, exposure to CaP risk factors, variation in genomic susceptibility, and other biological factors. To date, the proportion of CaP that can be explained by environmental exposures is small and differences in the role factors play by race or ethnicity is poorly understood. In the absence of additional data, it is likely that environmental factors do not contribute greatly to CaP disparities. In contrast, CaP has one of the highest heritabilities of all major cancers and many $\mathrm{CaP}$ susceptibility genes have been identified. Some CaP loci, including the risk loci found at chromosome 8q24, have consistent effects in all racial/ethnic groups studied to date. However, replication of many susceptibility loci across race or ethnicity remains limited. It is likely that inequities in health care access strongly influences $\mathrm{CaP}$ disparities. CaP is a disease with a complex multifactorial etiology, and therefore any approach attempting to address racial/ethnic disparities in CaP must consider the many sources that influence risk, outcomes, and disparities.

\section{WHAT DO THE RACIAL/ETHNIC DISPARITIES IN PROSTATE CANCER LOOK LIKE?}

Theri here are substantial differences in rates of prostate cancer $(\mathrm{CaP})$ across $\mathrm{racial} /$ ethnic groups that represent important disparities in $\mathrm{CaP}$ risk and outcomes. Disparities in $\mathrm{CaP}$ rates appear at all stages of the continuum of prostate carcinogenesis. Figure 1 shows the ratio of rates between African American (AA) and European American (EA) men for high-grade prostatic epithelial neoplasia (HGPIN) (Sakr et al. 1994), prevalent (autopsy-detected) CaP (Rebbeck and Haas 2014), incident $\mathrm{CaP}$, and $\mathrm{CaP}$ mortality (see seer.cancer.gov). At almost every point along the $\mathrm{CaP}$ continuum and for most every age group, $\mathrm{CaP}$ is more common in $\mathrm{AA}$ men than EA men. These data suggest that the disparity may have a biological component, as the disparity is evident even before cancer is usually clinically detected. However, the AA: EA disparity increases in magnitude in clinically detected disease and mortality, suggesting that factors related to exposure, behavior, or access to care are also important factors in $\mathrm{CaP}$ disparities. The metrics shown in Table 1 and discussed below similarly reveal a complex picture of $\mathrm{CaP}$ disparities.

Editors: Michael M. Shen and Mark A. Rubin

Additional Perspectives on Prostate Cancer available at www.perspectivesinmedicine.org

Copyright (C) 2018 Cold Spring Harbor Laboratory Press; all rights reserved; doi: 10.1101/cshperspect.a030387

Cite this article as Cold Spring Harb Perspect Med 2018;8:a030387 
T.R. Rebbeck

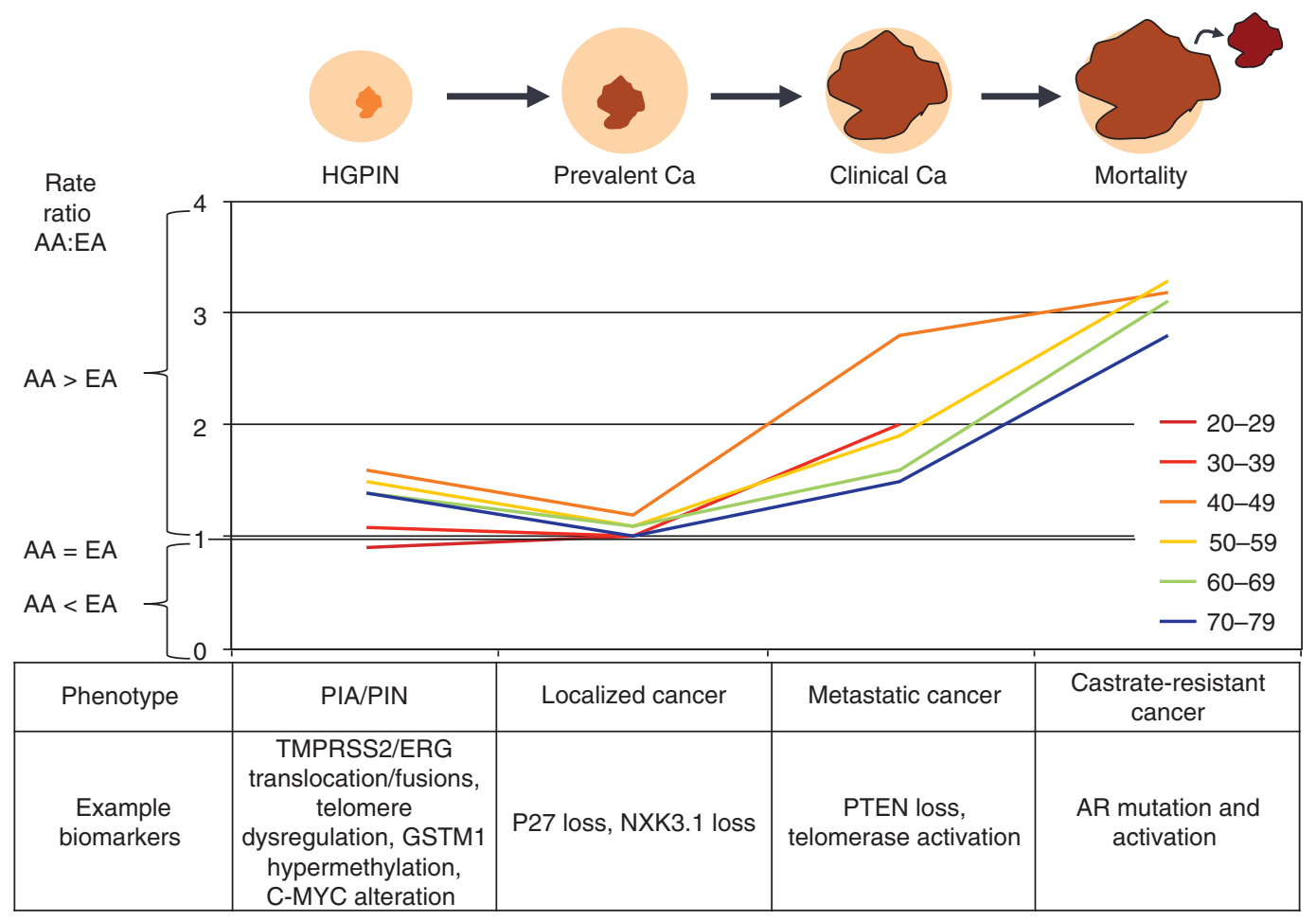

Figure 1. Depiction of disparities across the continuum of prostate cancer $(\mathrm{CaP})$ progression from high-grade prostatic intraepithelial neoplasia (HGPIN) to prevalent (autopsy-detected) CaP, to clinically detected CaP, and $\mathrm{CaP}$ mortality. Chart reflects the ratio of rates for African Americans (AAs) compared with European Americans (EAs). Potential biomarkers acting at each stage in this continuum are depicted below the chart. PIA, Polysaccharide intercellular adhesin; PIN, prostatic intraepitheilial neoplasia; PTEN, phosphatase and tensin homolog; $\mathrm{AR}$, androgen receptor.

As suggested in Figure 1, CaP disparities are evident even in latent prostate tumors identified in autopsy studies (Rebbeck and Haas 2014). Latent tumor prevalence is highest in Africandescent men, intermediate in European-descent men, and lowest in Asian-descent men. The disparity in $\mathrm{CaP}$ prevalence is apparent when it is observed that $50 \%$ of Asian men have prevalent CaP by age 90 but $50 \%$ by age 80 , and $50 \%$ of African-descent men by age 60 (Rebbeck and Haas 2014).

There is a similar disparity in the prevalence of screened-detected cancers. The rate of $\mathrm{CaP}$ detection in AA men is consistently higher than in EA men in the United States (Richie et al. 1993; Smith et al. 1996; Weinrich et al. 1998; Cooney et al. 2001; Powell 2007). In addition, the prevalence of screened detected cancers in
Ghanaian men is higher than that reported in any AA population, suggesting the rates of $\mathrm{CaP}$ in Africa may equal or exceed those in AAs (Hsing et al. 2014) and that elevated $\mathrm{CaP}$ rates are a phenomenon of men of African ancestry throughout the African diaspora.

It is also well known that population-based $\mathrm{CaP}$ incidence and mortality vary substantially by race/ethnicity. For example, SEER-18 data from 2008 to 2012 (see seer.cancer.gov) estimated that age-adjusted $\mathrm{CaP}$ incidence in $\mathrm{AAs}$ (214.5 per 100,000 men) is substantially greater than in non-Hispanic Whites (NHWs; 130.4 per 100,000 men) (Table 1). This represents a $64 \%$ greater incidence in AA versus NHW men. CaP mortality statistics are even more sobering: mortality in AA men is 46.3 per 100,000 compared with 19.8 per 100,000 in NHW-a $134 \%$ mor- 
Prostate Cancer Disparities by Race and Ethnicity

Table 1. Prostate cancer disparities metrics

\begin{tabular}{|c|c|c|c|c|}
\hline \multirow{2}{*}{$\begin{array}{l}\text { End point } \\
\text { Autopsy prevalence (\%) by } \\
\text { decade of age }\end{array}$} & \multicolumn{3}{|c|}{ Group and metric } & \multirow[b]{2}{*}{ References } \\
\hline & Asian Ancestry & $\begin{array}{l}\text { European } \\
\text { Ancestry }\end{array}$ & $\begin{array}{l}\text { African } \\
\text { Ancestry }\end{array}$ & \\
\hline $20-29$ & 0.0 & 0.5 & 1.6 & Rebbeck and Haas 2014 \\
\hline $30-39$ & 4.0 & 8.4 & 35.5 & \\
\hline $40-49$ & 6.3 & 15.0 & 24.7 & \\
\hline $50-59$ & 17.3 & 26.9 & 39.6 & \\
\hline $60-69$ & 17.7 & 33.3 & 56.7 & \\
\hline $70-79$ & 25.4 & 35.4 & NA & \\
\hline $80-89$ & 33.2 & 49.0 & NA & \\
\hline $90+$ & 50.0 & 91.1 & NA & \\
\hline $\begin{array}{l}\text { Screened-detected cancer } \\
\text { prevalence, men with PSA }\end{array}$ & & & & \\
\hline$>4.0$ and abnormal DRE & Prevalence & Group & & \\
\hline Ghana & 5.8 & Age $50-74$ & & Hsing et al. 2014 \\
\hline AA-St. Louis, MO & 5.4 & Age $40-79$ & & Smith et al. 1996 \\
\hline AA-Detroit, MI & 3.3 & Age $40-79$ & & Powell 2007 \\
\hline AA-Flint, MI & 3.0 & Age $40-79$ & & Cooney et al. 2001 \\
\hline AA-South Carolina & 2.2 & Age $40-79$ & & Weinrich et al. 1998 \\
\hline U.S. Caucasians & 1.6 & Age $>50$ & & Richie et al. 1993 \\
\hline $\begin{array}{l}\text { Incidence (age-adjusted per } \\
100,000 \text { men) }\end{array}$ & $\begin{array}{l}\text { SEER-18 rate } \\
2008-2012\end{array}$ & $\begin{array}{l}\text { SEER-13 trend } \\
\text { 2003-2012 }\end{array}$ & & \\
\hline Asian/Pacific Islander & 74.0 & -4.6 & & seer.cancer.gov \\
\hline Black & 214.5 & -3.9 & & \\
\hline Hispanic & 114.7 & -4.7 & & \\
\hline Non-Hispanic White & 133.4 & -4.7 & & \\
\hline $\begin{array}{l}\text { Relative biochemical } \\
\text { nonfailure, White vs. Black }\end{array}$ & $\mathrm{HR}=1.25$ & 95\% CI: 1.11-1.41 & & Evans et al. 2008 \\
\hline $\begin{array}{l}\text { Relative CaP-specific survival, } \\
\text { White vs. Black }\end{array}$ & $\mathrm{HR}=1.13$ & $95 \%$ CI: $1.00-1.27$ & & Evans et al. 2008 \\
\hline $\begin{array}{l}\text { Relative overall survival, White } \\
\text { vs. Black }\end{array}$ & $\mathrm{HR}=1.01$ & 95\% CI: 0.88-1.16 & & Evans et al. 2008 \\
\hline $\begin{array}{l}\text { Mortality (age-adjusted per } \\
100,000 \text { men }\end{array}$ & $\begin{array}{l}\text { SEER-18 rate } \\
2008-2012 \\
\end{array}$ & $\begin{array}{l}\text { SEER-13 trend } \\
2003-2012 \\
\end{array}$ & & \\
\hline Asian/Pacific Islander & 9.4 & -3.4 & & seer.cancer.gov \\
\hline Black & 46.3 & -4.0 & & \\
\hline Hispanic & 17.8 & -2.7 & & \\
\hline Non-Hispanic White & 19.9 & -3.4 & & \\
\hline
\end{tabular}

NA, Not available; AA, African American; PSA, prostate-specific antigen; DRE, digital rectal examination. 
T.R. Rebbeck

tality difference. This is the largest disparity in cancer mortality of any tumor site in U.S. men or women.

Although these statistics are grim, they represent an improvement in $\mathrm{CaP}$ disparities that existed only a few years ago. As shown in Figure 2, data from U.S. Mortality Files from the National Center for Health Statistics of the Centers for Disease Control and Prevention (CDC) indicate that the disparity in $\mathrm{CaP}$ mortality grew during the period from the mid-1980s to 2005 , in which prostate-specific antigen (PSA) screening became widespread. Since 2010, the disparity in mortality between AAs and NHWs has dropped, although a significant disparity in mortality still exists. The data in Figure 2 also indicate that the disparity in $\mathrm{CaP}$ mortality is age-dependent, with greatest disparities in $\mathrm{CaP}$ mortality occurring in men under age 75.

Finally, although it is clear that there is substantial disparity at all phases of the CaP continuum, data suggest that there is racial/ethnic disparity in certain $\mathrm{CaP}$-related parameters but not others. For example, a meta-analysis by Evans et al. (2008) reported no disparity in overall survival by race, but did find evidence for a difference in CaP-specific survival and biochemical (PSA) failure. Similarly, it has been suggested that racial differences in $\mathrm{CaP}$ mortality diminish or disappear in certain patient subgroups or if treatment is equalized among all patients (Powell et al. 2004). However, not all studies have been clearly able to show that equal treatment leads to equal outcome. Godley et al. (2003) used SEERMedicare data diagnosed with clinically localized CaP at ages 65-84 between 1986 and 1996 in five SEER sites. Those data suggest that mortality rates varied within screening, treatment, and racial groups. The data available to date do not completely resolve the question whether racial disparities could be eliminated if treatment were equalized among all cases. Similarly, the literature is not yet clear whether all CaP-related metrics show a meaningful disparity.

\section{WHAT FACTORS EXPLAIN PROSTATE CANCER DISPARITIES?}

The observed disparities in $\mathrm{CaP}$ discussed above may be explained by a wide variety of biological, social, environmental, health care, and other factors. Each of these may contribute to the disparity in some individuals or groups. Figure 3 represents a framework for the role of multiple factors on racial/ethnic disparities (Rebbeck and Sankar 2005; Rebbeck et al. 2006). This framework identifies self-identified race or ethnicity as being correlated with cultural, environmental,

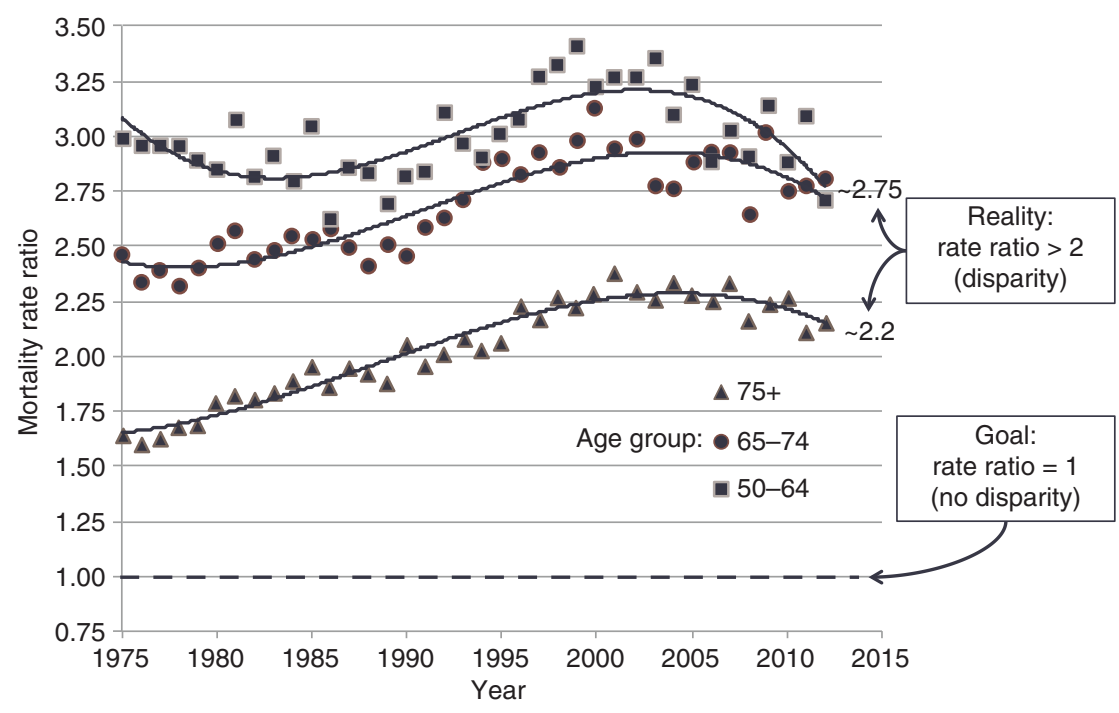

Figure 2. Ratio of African American (AA) versus European American (EA) mortality rates by age group and year. 


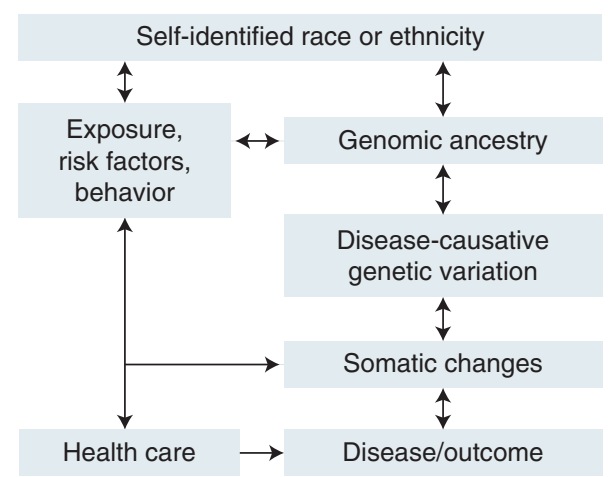

Figure 3. Framework for the definition of factors that underlie self-identified race or ethnicity that may influence prostate cancer $(\mathrm{CaP})$ etiology and disparities.

or behavioral factors. These factors are correlated both with race/ethnicity and may be associated with CaP. Similarly, race/ethnicity is correlated with phenotypic characteristics related to an individual's continental ancestry. Ancestry itself is associated with genome-wide variation, which in turn is correlated to genotype and mutation frequencies across populations. Inherited genotypes and environments (exposures) are further associated with the etiology of disease and tissue/tumor-specific changes that are associated with disease risk. In the following sections, the role of each of these factors on $\mathrm{CaP}$ disparities is discussed.

\section{Ancestry}

Self-identified race and ethnicity are commonly used to identify groups that may experience disparities in disease risk or outcomes. However, most populations, and particularly AAs and Hispanics in the United States, represent genomically admixed populations. This admixture is reflected in an individual's genetic background, which may provide additional information about the disparity and its causes than selfreported race or ethnicity. It is still common in epidemiological studies to categorize people into a few self-identified races that partly reflect the complicated history of each group, yet these categories cannot capture the specific contributions from ancestral populations (Yaeger et al. 2008). A number of groups have reported that
Prostate Cancer Disparities by Race and Ethnicity

there is substantial heterogeneity in the African source of the genome of AAs (Stefflova et al. 2009, 2011), as well as non-African contributions to self-identified AAs (Parra et al. 2001). More recent studies have suggested that ancestral genome may itself be associated with $\mathrm{CaP}$ risk or outcome (Giri et al. 2009). These data suggest that features of the African genome found in AAs or other populations may be correlated with risk alleles that are common in African-descent individuals. Further research is needed to explain the nature and potential mechanism of this association, but it provides an opportunity to extend our understanding and definition of race or ethnicity beyond selfreport to understand $\mathrm{CaP}$ disparities.

\section{Genetics and Genomics}

$\mathrm{CaP}$ shows the highest reported heritability of any major cancer (Lichtenstein et al. 2000; Verhage et al. 2004; Hjelmborg et al. 2014; Mucci et al. 2016), yet, unlike other cancers, the ability to define hereditary $\mathrm{CaP}$ syndromes and identify hereditary cancer genes has been limited. Family-based linkage studies of hereditary $\mathrm{CaP}$ focused largely on European-descent populations to identify a series of genes responsible for hereditary CaP. These include HPC1 (1q24-25) (Carter et al. 1992; Cooney et al. 1997; Berry et al. 2000a), PCAP (1q42-43) (Neuhausen et al. 1999; Berry et al. 2000a; Xu et al. 2001), HPCX (Xq27-28) (Schleutker et al. 2000), CAPB (1q36) (Berry et al. 2000a; Xu et al. 2001), HPC20 (20q13) (Berry et al. 2000b), HOXB13 (Breyer et al. 2012; Xu et al. 2013), and others. Among these, a series of loci were identified specifically or confirmed in non-European-descent families by family studies, including 12q24 (Ledet et al. 2012), 1q24-25, 2p16, and 2p21 (Brown et al. 2004; Ledet et al. 2012), and 1 p36 in Japanese (Matsui et al. 2004) and AA (Brown et al. 2004) men. Additional linkage signals have been detected in AA pedigrees at 2p21, 11q22, 17p11, 22q12, and Xq21 (Baffoe-Bonnie et al. 2007) among others. Many of these loci were validated across ethnic and geographic populations, suggesting common origins for some hereditary CaP susceptibility. 
T.R. Rebbeck

Despite the success of these discovery efforts, and the suggestion that there may be unique genetic loci associated with hereditary $\mathrm{CaP}$ in minority populations, genetic testing for hereditary $\mathrm{CaP}$ and recommendations for reduction of that risk based on genetic information have not evolved into clinical practice as has been the case for many other cancer sites. Recently, potentially clinically meaningful associations have been identified, including associations of inherited mutations in BRCA2 and aggressive $\mathrm{CaP}$, with implications for treatment (Castro et al. 2013; Cheng et al. 2016). However, the data addressing the potential that these loci confer different risks or occur at different frequencies in AAs or other high-risk groups has not been reported.

Candidate gene association studies in $\mathrm{CaP}$ and other diseases were quite common before the advent of the genome-wide association studies (GWAS). These studies identified genes that played a biologically plausible role in the etiology of a disease, from which individual single-nucleotide polymorphisms (SNPs) or haplotypes were studied in relation to disease phenotypes. Genes involved in DNA damage and repair, carcinogen metabolism, inflammation, steroid hormone metabolism, and many others have been reported in candidate gene association studies and have involved populations worldwide (reviewed in Naylor 2007). Of the many candidates that have been considered, few have also been reported in linkage or GWAS studies. Examples of candidate genes that have been identified using large gene panels or GWAS include the androgen receptor ( $A R$ [Kote-Jarai et al. 2011]), kallekrein genes (e.g., KLK3 that encodes PSA [Lose et al. 2013; Knipe et al. 2014; Lange et al. 2014]), telomere-related genes (TERT, TET [Kote-Jarai et al. 2011; Berndt et al. 2015]), and loci containing carcinogen metabolism (UGT1A8, CYP21A2 [Eeles et al. 2013]), microRNAs (Eeles et al. 2013), or matrix metalloprotein genes (Eeles et al. 2013). Many smaller studies have been undertaken in diverse populations around the world. However, the majority of these reports have not been validated in independent samples, and associations of most of these candidate loci have not been reported in GWAS studies.
Numerous CaP susceptibility loci have been reported to date using GWAS approaches. However, many loci detected in European or Asiandescent populations have not been replicated in African-descent populations, or the magnitude of effect was less (or directionally opposite) by race (Waters et al. 2009; Xu et al. 2009; Hooker et al. 2010). A number of studies have attempted to validate reported associations in AAs. Xu et al. (2009) studied 868 cases and 878 controls and validated the loci at $8 \mathrm{q} 24(p=0.034$ to $p=2 \times$ $\left.10^{-5}\right)$ and 3 p12 $(p=0.029)$. Waters et al. (2009) studied 860 cases and 575 controls, and validated KLK2/3 (19q13.33) and NUDT10/11 (Xp11.22). Finally, Hooker et al. (2010) validated 8q24 ( $p=$ $\left.1 \times 10^{-4}\right), 11 \mathrm{q} 13.2(p=0.009)$, HNF1B/TCF2 (17q12; $p=0.008), \quad K L K 2 / 3 \quad(19 q 13.33 ; p=$ 0.04 ), and NUDT11 (Xp11.22; $p=0.05$ ) in 454 cases and 301 controls. The validated loci were not consistent across these studies, perhaps because of relatively small sample sizes in each study. Chang et al. (2011) studied a sample of nearly 8000 men of African descent in the United States and the United Kingdom. This report only involved those loci that had been previously reported in non-African-descent populations. They reported that the majority of the loci identified as $\mathrm{CaP}$ susceptibility loci in White or Asian populations were not replicated in AA men. Only JAZF1, MSMB, NUDT10/11, and a locus on 11q13 were validated as having effects similar to those in non-African-descent populations. The remainder of the associations in AAs showed smaller effects than those reported in non-AA populations. Some of the AA associations were even in the opposite direction of the non-AA reports, and, in many cases, the $95 \%$ confidence intervals for AA men did not overlap the non-AA estimates. Using a GWAS approach, Haiman and colleagues also did not replicate most of the previously reported loci identified in European- or Asian-descent populations (Haiman et al. 2011a,b). Using more than 9500 AA CaP cases and controls, Han et al. (2015) reported that of established 82 GWAS hits, only $68(83 \%)$ were directionally consistent with the original report, and $37 \%$ were significant at $p<0.05$. Similarly, the effect size of many loci is also smaller for the same locus in African- 
descent populations compared with the original report of these loci in European or Asian-descent populations.

In contrast, GWAS have identified alleles in African-descent populations. Variants at 17q21 reached genome-wide level significance in African-descent populations (Haiman et al. 2011a). This locus has since been validated as a CaP risk locus in European-descent populations (Eeles et al. 2013). A novel locus at chromosome 10p14 was reported in a GWAS undertaken in a Ghanaian population (Cook et al. 2014), although this association did not reach genome-wide significance.

A number of hypotheses have been proposed to explain the difficulty in replication and systematic differences in magnitudes of genetic effects by race and ethnicity. First, the underlying genomic susceptibility, and thus biology, for $\mathrm{CaP}$ may differ fundamentally across racial or ethnic groups. This explanation is unlikely to be the case, as it implies that the biological basis for CaP differs by race or ethnicity. However, this hypothesis cannot be ruled out based on available data. A more likely explanation is that the risk alleles in European-/Asian-descent individuals are not the same as in African-descent individuals. It is likely that the risk alleles and the underlying population structure of $\mathrm{CaP}$ susceptibility loci differ by ethnicity, race, or geography, and that these differences are likely to influence the ability to detect genetic associations (Teo et al. 2010). This hypothesis is supported by well-described differences in the genomic architecture of the genome by race and ethnicity. Linkage disequilibrium and haplotype diversity differ substantially by race and ethnicity (Reich et al. 2001; Teo et al. 2010), as do allele frequencies at many loci across the genome. The capture of genomic variability is incomplete, and it is likely that many African-specific alleles have yet to be detected that may provide a better capture of the African genome. Indeed, the diversity of the African genome is so great that capture of continent-wide genomic variation may be required to fully understand the genomic basis of $\mathrm{CaP}$ in African ancestry populations. Thus, it is not hard to imagine that $\mathrm{CaP}$ risk alleles and the frequencies of these alleles vary substantially
Prostate Cancer Disparities by Race and Ethnicity

across populations to affect the ability to detect associations in a GWAS setting. To address this hypothesis, additional studies using non-Caucasian populations will be required that use genotyping panels that adequately capture African genomic variability. Although generally unreported in the GWAS literature, similar arguments can be made regarding genomics of other populations that are genomically divergent from Caucasians, including Native Americans, Middle Eastern groups, and aboriginal populations in the Arctic, Oceania, and elsewhere.

Furthermore, it is likely that the underlying etiology of $\mathrm{CaP}$ is not only influenced by genes but also by exposures and gene by environment interactions. The different magnitudes of effect observed across race, ethnicity, and geography could be explained by the influence of contextual factors that influence $\mathrm{CaP}$ susceptibility through gene-environment interactions that may vary by population. The number of confirmed environmental factors or exposures that influence $\mathrm{CaP}$ risk and outcome are limited (Boffetta et al. 2009), but it is still possible that underlying genetic susceptibility may influence the effect of exposures that are not detectable on their own. To the degree that the frequencies of both the exposures and the susceptibility genotypes vary by race or ethnicity (which they are likely to do), it is possible that differences in etiology or severity of $\mathrm{CaP}$ could be explained by complex interactions of these factors. There have been published examples of gene-environment interactions in $\mathrm{CaP}$, including novel and biological plausible interactions (e.g., Koutros et al. 2013; Neslund-Dudas et al. 2014). However, most of these have not been validated in independent sets or across populations, and the large post-GWAS evaluations of GWAS loci have not shown convincing interaction results (Barrdahl et al. 2014). No major or replicated interaction studies have been undertaken across racially or ethnically diverse groups to be able to test the hypothesis that differences in geneenvironment interactions could explain differences in $\mathrm{CaP}$ etiology or severity.

Unlike many $\mathrm{CaP}$ susceptibility loci for which variation and lack of replication has been observed, genetic variation at chromosome 
T.R. Rebbeck

$8 \mathrm{q} 24$ has been widely and consistently associated with prostate and numerous other cancers across many populations (Amundadottir et al. 2006). Originally identified by admixture mapping methods, this locus has an overrepresentation of African genomic ancestry in AA men (Freedman et al. 2006). At least eight independent genomic regions conferring $\mathrm{CaP}$ susceptibility have been identified at this locus (Gudmundsson et al. 2007; Haiman et al. 2007; Yeager et al. 2007), although no gene has been designated to be responsible for this cancer risk. Instead, regulation of the downstream gene MYC or regulation by long noncoding RNAs (lncRNAs) has been reported (Ahmadiyeh et al. 2010; Chung et al. 2011; Kim et al. 2014). Disease-associated variation at $8 \mathrm{q} 24$ has been confirmed in multiple populations. Indeed, the $8 \mathrm{q} 24$ locus was associated with $\mathrm{CaP}$ in early admixture mapping studies (Freedman et al. 2006) that identify susceptibility loci by exploiting different disease risks and genotype distributions by race. Ethnic-specific mutations and haplotypes have been reported in African- and European-descent populations (Chung et al. 2014; Han et al. 2016). The associations at $8 q 24$ have been confirmed not only in AAs, but also in two African populations (Han et al. 2016). Thus, the genetic contribution to $\mathrm{CaP}$ risk at this locus can be considered a master regulator of cancer at multiple sites as well as across populations.

\section{Tumor Biomarkers}

In addition to the strong evidence for inherited genomic factors influencing $\mathrm{CaP}$, and potentially having different effects by race, somatic biomarkers found in prostate tissue and tumors may also play a role in CaP etiology and disparities. The biomarkers identified to date may improve screening for $\mathrm{CaP}$ (e.g., as an alternative or supplement to PSA testing) and might inform treatment choices and prognosis. A number of prostate tumor biomarkers have been identified that may define heterogeneity of $\mathrm{CaP}$ etiology (Ahearn et al. 2015; Graff et al. 2016a) have clinical implications for surveillance and treatment (reviewed in Netto 2013), or correlate with aggressive phenotypes (Lee et al. 1994; Li et al.
2004; Bjartell et al. 2007; Perner et al. 2007a,b; Attard et al. 2008; Berney et al. 2009; Fine et al. 2010). These biomarkers show promise as predictors of aggressive disease with potential clinical utility and act across the prostate carcinogenesis continuum (Fig. 1). The most notable examples include the TMPRSS2:ERG gene fusion/translocation (Demichelis et al. 2007), Ki67 expression (Berney et al. 2009), biomarkers involved in androgen metabolism (Li et al. 2004; Wandel et al. 2000), and genomic classifiers (GCs) that use whole-transcriptome microarray assays to analyze gene activity in $\mathrm{CaP}$ specimens (Erho et al. 2012). In general, the majority of the studies of these biomarkers has been in European- or Asian-descent populations, and there are limited data that evaluate whether these markers have similar distributions or confer similar effects on outcomes in African-descent populations. A few studies have begun to report differences in biomarkers between AA and EA men, including AMCAR, ERG, SPINK1, NXK3.1, GOLM1, AR, Ki67, and SRD5A2 (Khani et al. 2014; Yamoah et al. 2015a). These studies remain limited by smaller sample sizes but suggest that biological differences in tumor features by race exist and could affect clinical parameters of $\mathrm{CaP}$ aggressiveness.

TMPRSS2:ERG translocations have been reported as having a different frequency by race. Magi-Galluzzi et al. (2011) reported that the frequency of TMPRSS2:ERG translocations was highest in Japanese (71\%) and Caucasians (62\%) and much lower in AAs (20\%). Yamoah et al. (2015a) also reported significant differences in ERG expression between EA and AA $\mathrm{CaP}$ cases. Although the prognostic value of TMPRSS2:ERG translocations and ERG expression is not clear, it does not seem to correlate with clinical outcome in most studies (Pettersson et al. 2012). However, the underlying marker distribution may identify tumor heterogeneity that informs $\mathrm{CaP}$ etiology and disparities. For example, it is becoming clear that the relationship of potential $\mathrm{CaP}$ risk factors differs by TMPRSS2:ERG translocation status (Ahearn et al. 2015; Graff et al. 2016a,b). Although not formally evaluating a racially diverse group, Pettersson et al. (2013) reported that the rela- 
tionship of obesity and lethal CaP varied by TMPRSS2:ERG translocation status. Because obesity has been associated with poorer $\mathrm{CaP}$ outcomes in some studies, and AA and Hispanic men tend to have greater rates of obesity than other racial/ethnic groups, this biomarker may prove valuable in understanding poor outcomes in some men.

\section{Epidemiological Risk Factors}

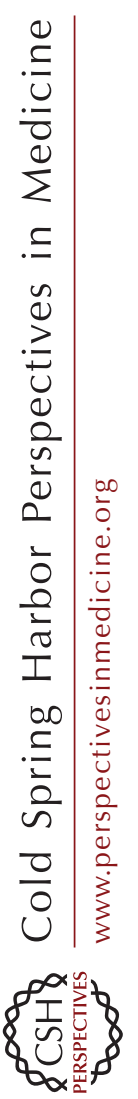

The proportion of $\mathrm{CaP}$ that can be explained by known risk factors is one of the lowest of all common cancers (Boffetta et al. 2009). As a result, the ability to identify risk factors that may explain disparities is limited. The only clear and consistent $\mathrm{CaP}$ risk factors are age, race, and family history. Numerous reports of exposures such as Agent Orange, diet, lifestyle, and others have been proposed as $\mathrm{CaP}$ risk factors. However, the effects of most of these exposures has been controversial and confer at best small magnitudes of effect in the normal ranges of exposure for most men. Furthermore, most of the studies that have provided evidence for exposures or lifestyle and CaP risk have been undertaken in largely Caucasian study samples. Extensive epidemiological evaluation of $\mathrm{CaP}$ risk factors has not been available in AA men. Therefore, it is unclear whether these factors confer substantial risk of $\mathrm{CaP}$ and if the disparity in $\mathrm{CaP}$ can be explained by these factors.

\section{Residential Factors}

Residential characteristics have been suggested as a meaningful surrogate for identifying groups of individuals who live in settings that may influence their cancer risk and prognosis (Paskett 2016). As a result, studies have begun to evaluate the effect of residential or workplace factors using geospatial methods. Studies of neighborhood and $\mathrm{CaP}$ suggest that men who live in neighborhoods with an unfavorable socioeconomic status are more likely to be diagnosed with high-grade CaP (Wardle et al. 2003; Borrell et al. 2004; Messer et al. 2006; Diez Roux and Mair 2010). These effects appear to act over and above an individual's risk factors (Byers et al.
2008; Carpenter et al. 2010; Lyratzopoulos et al. 2010; Ziegler-Johnson et al. 2011). These associations include variables from the U.S. Census (United States Census Bureau 2007) related to education, income, poverty, and employment (Stoll 2000; Diez Roux and Mair 2010; Diez Roux et al. 2002; Wardle et al. 2003; Borrell et al. 2004; Robert and Reither 2004; Robert et al. 2004; Messer et al. 2006; Byers et al. 2008; Carpenter et al. 2010; Ziegler-Johnson et al. 2011), as well as access to public transportation or living in a rural versus urban area, perhaps reflecting access to medical care (Carriere et al. 2013; Schupp et al. 2014). Although studies of this type are currently limited, they provide the potential to identify groups of men who reside in neighborhoods that require special attention in terms of screening or treatment by population or public health approaches. Ongoing initiatives such as the Precision Medicine Initiative that will include a wide range of demographic groups are critical to achieve these goals.

\section{Health Care and Health Status}

It is not yet clear what proportion of the racial disparity in CaP may be attributed to biological factors, but it is likely that access to health care (and its social, economic, and behavioral correlates) are strongly associated with $\mathrm{CaP}$ disparities. A wide variety of studies support this hypothesis. For example, Godley et al. (2003) reported that racial differences in mortality among Medicare recipients with localized $\mathrm{CaP}$ persist even after correction for treatment type. Other studies report that the care received by AAs or Hispanic men differs in terms of quality, which in turn affects outcomes and disparities (Jayadevappa et al. 2011a,b). Disparities in outcome persist even within settings in which men of different races have equality of care (e.g., in the VA system, within a clinical trial, or treatment by standard protocols at a single institution (Thompson et al. 2006; Hamilton et al. 2007; Kane et al. 2010; Barocas et al. 2013; Yamoah et al. 2015b). Other studies report that the disparity by race disappears after equal clinical protocols are applied or if sociodemographic variables such as education and literacy are tak- 
T.R. Rebbeck

en into account (Gann et al. 2010). There is also evidence that race itself is not associated with some clinical parameters when treatment is equalized by race (Bañez et al. 2009). However, the literature suggesting differences by race even after accounting for known prognostic factors have led to proposals for more aggressive clinical interventions for some AA men (Sundi et al. 2013).

Similarly, use of PSA screening, although highly controversial in recent years, is also likely to impact on $\mathrm{CaP}$ disparities. To the degree that AA men are less likely to undergo PSA screening than EA men (French and Jones 2005) and delayed diagnosis is correlated with poorer outcomes, AA men may be at greater risk of poorer outcomes because of screening practices. Where equal access to screening is possible (e.g., the VA system), rates of PSA screening may not differ, and the potential for screening as a cause of disparity is limited (Hudson et al. 2014).

Prediction of $\mathrm{CaP}$ outcomes may involve not only clinical criteria related to the $\mathrm{CaP}$ diagnosis itself, but also to non-CaP characteristics of the individual. For example, the presence of comorbid conditions may influence the clinician to assess whether a patient will be able to benefit from a specific medical intervention, including active surveillance. Metrics of comorbidity include individual conditions as well as multicondition indices. Individual conditions of interest include a history of myocardial Infarction, congestive heart failure, peripheral vascular disease, cerebrovascular disease, dementia, chronic obstructive pulmonary disease, connective tissue disease, peptic ulcer disease, diabetes mellitus, chronic kidney disease, hemiplegia, other cancer diagnoses, liver disease, and infectious diseases, including hepatitis B, AIDS, and others.

A variety of indices have been developed that attempt to create a simple metric that capture multivariate comorbidity data (reviewed in Sarfati 2012). These include indices that are counts of individual conditions, organ- and systembased approaches, and weighted indices. In each category, the indices have been developed using cancer and noncancer patient populations, most of which are not $\mathrm{CaP}$ specific. In $\mathrm{CaP}$, a series of indices have been developed for or evaluated. These include indices specific to older $\mathrm{CaP}$ cases, early-stage disease, late-stage disease, and men considering specific treatments (Stier et al. 1999; Fleming et al. 2006; Litwin et al. 2007; Liss et al. 2013). Only one study to date has assessed comorbidity in AA $\mathrm{CaP}$ cases (Fleming et al. 2003), and there is thus limited information about the value of comorbidity and other clinical parameters in assessing clinical outcomes and disparity in men diagnosed with CaP. However, because AA and Hispanic men tend to have higher rates of relevant comorbidities than EA or Asian men, the potential contribution of comorbid factors on treatment choice and outcomes remains an area of research need.

\section{CAN RACIAL/ETHNIC DISPARITIES IN PROSTATE CANCER BE ELIMINATED?}

It is possible to divide the disparity-related factors described above into those that represent differences, and those that represent inequities (Graham 2004). Differences include genetics, race/ethnicity, behavior, biology, lifestyle, and environmental exposures. Inequities include factors such as discrimination, segregation, and access to health care. It is not generally possible to modify innate factors such as ancestry or inherited susceptibility, but these factors may serve as risk stratifiers that can be used to identify high-risk individuals and develop targeted interventions. Given the potential differences in genomic risk by race/ethnicity, it is possible that race- or ancestry-specific high-risk strategies may be developed once sufficient information about race/ethnicity/ancestral risk is understood. In contrast, social or political change may be required to address inequities that lead to disparities. It is possible to develop interventions to modify behavior, biology, lifestyle, and environmental exposures by a variety of means. Intervention on biological traits by chemoprevention or other exposure modification of $\mathrm{CaP}$ has been attempted in a variety of settings, including the use of finasteride (Goodman et al. 2006). Race/ethnicity/ancestry-specific approaches to these interventions may be worth consideration, as some of these have not been 
shown to be effective in the population as a whole. However, because the role of many behavioral, lifestyle, or exposure factors have not been strongly associated with $\mathrm{CaP}$ or $\mathrm{CaP}$ disparities, it remains unclear what role modification of these factors can have in eliminating $\mathrm{CaP}$ disparities.

Based on these observations, it is likely that a personalized approach to $\mathrm{CaP}$ prevention and treatment may be required. Rather than focus solely on race/ethnicity-specific differences and target large demographically defined groups, basic discovery of underlying risk factors and genomics may be required to understand and address an individual's risk, prevention, and treatment options. These risk factors and genomic traits may (strongly) correlate with race or ethnicity, but the continued use of race/ethnicity as the stratifier around which $\mathrm{CaP}$ prevention and treatment is based may have limited efficacy. Thus, a precision medicine approach to addressing $\mathrm{CaP}$ disparities should be prioritized as a means of eliminating $\mathrm{CaP}$ disparities by race/ ethnicity.

\section{REFERENCES}

Ahearn TU, Pettersson A, Ebot EM, Gerke T, Graff RE, Morais CL, Hicks JL, Wilson KM, Rider JR, Sesso HD, et al. 2015. A prospective investigation of PTEN loss and ERG expression in lethal prostate cancer. J Natl Cancer Inst 108: djv346.

Ahmadiyeh N, Pomerantz MM, Grisanzio C, Herman P, Jia L, Almendro V, He HH, Brown M, Liu XS, Davis M, et al. 2010. $8 \mathrm{q} 24$ prostate, breast, and colon cancer risk loci show tissue-specific long-range interaction with MYC. Proc Natl Acad Sci 107: 9742-9746.

Amundadottir LT, Sulem P, Gudmundsson J, Helgason A, Baker A, Agnarsson BA, Sigurdsson A, Benediktsdottir KR, Cazier JB, Sainz J, et al. 2006. A common variant associated with prostate cancer in European and African populations. Nat Genet 38: 652-658.

Attard G, Clark J, Ambroisine L, Fisher G, Kovacs G, Flohr P, Berney D, Foster CS, Fletcher A, Gerald WL, et al. 2008. Duplication of the fusion of TMPRSS2 to ERG sequences identifies fatal human prostate cancer. Oncogene 27: 253 263.

Baffoe-Bonnie AB, Kittles RA, Gillanders E, Ou L, George A, Robbins C, Ahaghotu C, Bennett J, Boykin W, Hoke G, et al. 2007. Genome-wide linkage of 77 families from the African American Hereditary Prostate Cancer study (AAHPC). Prostate 67: 22-31.

Bañez LL, Terris MK, Aronson WJ, Presti JC Jr, Kane CJ, Amling CL, Freedland SJ. 2009. Race and time from diag- nosis to radical prostatectomy: Does equal access mean equal timely access to the operating room?-Results from the SEARCH database. Cancer Epidemiol Biomarkers Prev 18: 1208-1212.

Barocas DA, Grubb R III, Black A, Penson DF, Fowke JH, Andriole G, Crawford ED. 2013. Association between race and follow-up diagnostic care after a positive prostate cancer screening test in the prostate, lung, colorectal, and ovarian cancer screening trial. Cancer 119: 2223-2229.

Barrdahl M, et al. 2014. Post-GWAS gene-environment interplay in breast cancer: Results from the Breast and Prostate Cancer Cohort Consortium and a meta-analysis on 79,000 women. Hum Mol Genet 23: 5260-5270.

Berndt SI, Wang Z, Yeager M, Alavanja MC, Albanes D, Amundadottir L, Andriole G, Beane Freeman L, Campa D, Cancel-Tassin G, et al. 2015. Two susceptibility loci identified for prostate cancer aggressiveness. Nat Commun 6: 6889 .

Berney DM, Gopalan A, Kudahetti S, Fisher G, Ambroisine L, Foster CS, Reuter V, Eastham J, Moller H, Kattan MW, et al. 2009. Ki-67 and outcome in clinically localised prostate cancer: Analysis of conservatively treated prostate cancer patients from the Trans-Atlantic Prostate Group study. Br J Cancer 100: 888-893.

Berry R, Schaid DJ, Smith JR, French AJ, Schroeder JJ, McDonnell SK, Peterson BJ, Wang ZY, Carpten JD, Roberts SG, et al. 2000a. Linkage analyses at the chromosome 1 loci 1q24-25 (HPC1), 1q42.2-43 (PCAP), and $1 \mathrm{p} 36$ (CAPB) in families with hereditary prostate cancer. Am J Hum Genet 66: 539-546.

Berry R, Schroeder JJ, French AJ, McDonnell SK, Peterson BJ, Cunningham JM, Thibodeau SN, Schaid DJ. 2000b. Evidence for a prostate cancer-susceptibility locus on chromosome 20. Am J Hum Genet 67: 82-91.

Bjartell AS, Al-Ahmadie H, Serio AM, Eastham JA, Eggener SE, Fine SW, Udby L, Gerald WL, Vickers AJ, Lilja H, et al. 2007. Association of cysteine-rich secretory protein 3 and $\beta$-microseminoprotein with outcome after radical prostatectomy. Clin Cancer Res 13: 4130-4138.

Boffetta P, Tubiana M, Hill C, Boniol M, Aurengo A, Masse R, Valleron AJ, Monier R, de Thé G, Boyle P, et al. 2009. The causes of cancer in France. Ann Oncol 20: 550-555.

Borrell LN, Taylor GW, Borgnakke WS, Woolfolk MW, Nyquist LV. 2004. Perception of general and oral health in White and African American adults: Assessing the effect of neighborhood socioeconomic conditions. Community Dent Oral Epidemiol 32: 363-373.

Breyer JP, Avritt TG, McReynolds KM, Dupont WD, Smith JR. 2012. Confirmation of the HOXB13 G84E germline mutation in familial prostate cancer. Cancer Epidemiol Biomarkers Prev 21: 1348-1353.

Brown WM, Lange EM, Chen H, Zheng SL, Chang B, Wiley KE, Isaacs SD, Walsh PC, Isaacs WB, Xu J, et al. 2004 Hereditary prostate cancer in African American families: Linkage analysis using markers that map to five candidate susceptibility loci. Br J Cancer 90: 510-514.

Byers TE, Wolf HJ, Bauer KR, Bolick-Aldrich S, Chen VW, Finch JL, Fulton JP, Schymura MJ, Shen T, Van Heest S, et al. 2008. The impact of socioeconomic status on survival after cancer in the United States. Cancer 113: 582-591.

Carpenter WR, Howard DL, Taylor YJ, Ross LE, Wobker SE, Godley PA. 2010. Racial differences in PSA screening 
T.R. Rebbeck

interval and stage at diagnosis. Cancer Causes Control 21 1071-1080.

Carriere GM, Sanmartin C, Bryant H, Lockwood G. 2013. Rates of cancer incidence across terciles of the foreignborn population in Canada from 2001-2006. Can J Public Health 104: e443-449.

Carter BS, Beaty TH, Steinberg GD, Childs B, Walsh PC. 1992. Mendelian inheritance of familial prostate cancer. Proc Natl Acad Sci 89: 3367-3371.

Castro E, Goh C, Olmos D, Saunders E, Leongamornlert D, Tymrakiewicz M, Mahmud N, Dadaev T, Govindasami K, Guy M, et al. 2013. Germline BRCA mutations are associated with higher risk of nodal involvement, distant metastasis, and poor survival outcomes in prostate cancer. $J$ Clin Oncol 31: 1748-1757.

Chang BL, Spangler E, Gallagher S, Haiman CA, Henderson B, Isaacs W, Benford ML, Kidd LR, Cooney K, Strom S, et al. 2011. Validation of genome-wide prostate cancer associations in men of African descent. Cancer Epidemiol Biomarkers Prev 20: 23-32.

Cheng HH, Pritchard CC, Boyd T, Nelson PS, Montgomery B. 2016. Biallelic inactivation of $B R C A 2$ in platinum-sensitive metastatic castration-resistant prostate cancer. Eur Urol 69: 995-995.

Chung S, Nakagawa H, Uemura M, Piao L, Ashikawa K, Hosono N, Takata R, Akamatsu S, Kawaguchi T, Morizono T, et al. 2011. Association of a novel long non-coding RNA in 8q24 with prostate cancer susceptibility. Cancer Sci 102: 245-252.

Chung CC, Hsing AW, Edward Yeboah, Biritwum R, Tettey Y, Adjei A, Cook MB, De Marzo A, Netto G, Tay E, et al. 2014. A comprehensive resequence-analysis of $250 \mathrm{~kb}$ region of 8q24.21 in men of African ancestry. Prostate 74 579-589.

Cook MB, Wang Z, Yeboah ED, Tettey Y, Biritwum RB, Adjei AA, Tay E, Truelove A, Niwa S, Chung CC, et al 2014. A genome-wide association study of prostate cancer in West African men. Hum Genet 133: 509-521.

Cooney KA, McCarthy JD, Lange E, Huang L, Miesfeldt S, Montie JE, Oesterling JE, Sandler HM, Lange K. 1997. Prostate cancer susceptibility locus on chromosome 1q A confirmatory study. J Natl Cancer Inst 89: 955-959.

Cooney KA, Strawderman MS, Wojno KJ, Doerr KM, Taylor A, Alcser KH, Heeringa SG, Taylor JM, Wei JT, Montie JE, et al. 2001. Age-specific distribution of serum prostatespecific antigen in a community-based study of AfricanAmerican men. Urology 57: 91-96.

Demichelis F, Fall K, Perner S, Andrén O, Schmidt F, Setlur SR, Hoshida Y, Mosquera JM, Pawitan Y, Lee C, et al. 2007. TMPRSS2:ERG gene fusion associated with lethal prostate cancer in a watchful waiting cohort. Oncogene 26: 4596-4599.

Diez Roux AV, Mair C. 2010. Neighborhoods and health. Ann NY Acad Sci 1186: 125-145.

Diez Roux AV, Jacobs DR, Kiefe CI. 2002. Neighborhood characteristics and components of the insulin resistance syndrome in young adults: The coronary artery risk development in young adults (CARDIA) study. Diabetes Care 25: 1976-1982.

Eeles RA, Olama AA, Benlloch S, Saunders EJ, Leongamornlert DA, Tymrakiewicz M, Ghoussaini M, Luccarini C, Dennis J, Jugurnauth-Little S, et al. 2013. Identification of 23 new prostate cancer susceptibility loci using the iCOGS custom genotyping array. Nat Genet 45: 385391, 391e1-2.

Erho N, Buerki C, Triche TJ, Davicioni E, Vergara IA. 2012. Transcriptome-wide detection of differentially expressed coding and non-coding transcripts and their clinical significance in prostate cancer. J Oncol 2012: 541353.

Evans S, Metcalfe C, Ibrahim F, Persad R, Ben-Shlomo Y. 2008. Investigating Black-White differences in prostate cancer prognosis: A systematic review and meta-analysis. Int J Cancer 123: 430-435.

Fine SW, Gopalan A, Leversha MA, Al-Ahmadie HA, Tickoo SK, Zhou Q, Satagopan JM, Scardino PT, Gerald WL, Reuter VE. 2010. TMPRSS2-ERG gene fusion is associated with low Gleason scores and not with high-grade morphological features. Mod Pathol 23: 1325-1333.

Fleming ST, Pearce KA, McDavid K, Pavlov D. 2003. The development and validation of a comorbidity index for prostate cancer among Black men. J Clin Epidemiol 56: 1064-1075.

Fleming ST, McDavid K, Pearce K, Pavlov D. 2006. Comorbidities and the risk of late-stage prostate cancer. ScientificWorldJournal 6: 2460-2470.

Freedman ML, Haiman CA, Patterson N, McDonald GJ, Tandon A, Waliszewska A, Penney K, Steen RG, Ardlie K, John EM, et al. 2006. Admixture mapping identifies $8 \mathrm{q} 24$ as a prostate cancer risk locus in African-American men. Proc Natl Acad Sci 103: 14068-14073.

French DB, Jones LA. 2005. Minority issues in prostate disease. Med Clin North Am 89: 805-816.

Gann PH, Fought A, Deaton R, Catalona WJ, Vonesh E. 2010. Risk factors for prostate cancer detection after a negative biopsy: A novel multivariable longitudinal approach. J Clin Oncol 28: 1714-1720.

Giri VN, Egleston B, Ruth K, Uzzo RG, Chen DY, Buyyounouski M, Raysor S, Hooker S, Torres JB, Ramike T, et al. 2009. Race, genetic West African ancestry, and prostate cancer prediction by prostate-specific antigen in prospectively screened high-risk men. Cancer Prev Res (Phila) 2: 244-250.

Godley PA, Schenck AP, Amamoo MA, Schoenbach VJ, Peacock S, Manning M, Symons M, Talcott JA. 2003. Racial differences in mortality among Medicare recipients after treatment for localized prostate cancer. J Natl Cancer Inst 95: 1702-1710.

Goodman PJ, Thompson IM Jr, Tangen CM, Crowley JJ, Ford LG, Coltman CA Jr. 2006. The prostate cancer prevention trial: Design, biases and interpretation of study results. J Urol 175: 2234-2242.

Graff RE, Meisner A, Ahearn TU, Fiorentino M, Loda M, Giovannucci EL, Mucci LA, Pettersson A. 2016a. Pre-diagnostic circulating sex hormone levels and risk of prostate cancer by ERG tumour protein expression. $\mathrm{Br} \mathrm{J} \mathrm{Can-}$ cer 114: 939-944.

Graff RE, Pettersson A, Lis RT, Ahearn TU, Markt SC, Wilson KM, Rider JR, Fiorentino M, Finn S, Kenfield SA, et al. 2016b. Dietary lycopene intake and risk of prostate cancer defined by ERG protein expression. Am J Clin Nutr 103: 851-860.

Graham H. 2004. Social determinants and their unequal distribution: Clarifying policy understandings. Milbank Q 82: 101-124. 
Gudmundsson J, Sulem P, Manolescu A, Amundadottir LT, Gudbjartsson D, Helgason A, Rafnar T, Bergthorsson JT, Agnarsson BA, Baker A, et al. 2007. Genome-wide association study identifies a second prostate cancer susceptibility variant at 8q24. Nat Genet 39: 631-637.

Haiman CA, Patterson N, Freedman ML, Myers SR, Pike MC, Waliszewska A, Neubauer J, Tandon A, Schirmer C, McDonald GJ, et al. 2007. Multiple regions within $8 \mathrm{q} 24$ independently affect risk for prostate cancer. Nat Genet 39: 638-644.

Haiman CA, Chen GK, Blot WJ, Strom SS, Berndt SI, Kittles RA, Rybicki BA, Isaacs WB, Ingles SA, Stanford JL, et al 2011a. Genome-wide association study of prostate cancer in men of African ancestry identifies a susceptibility locus at 17q21. Nat Genet 43: 570-573.

Haiman CA, Chen GK, Blot WJ, Strom SS, Berndt SI, Kittles RA, Rybicki BA, Isaacs WB, Ingles SA, Stanford JL, et al. 2011b. Characterizing genetic risk at known prostate cancer susceptibility loci in African Americans. PLoS Genet 7: e1001387.

Hamilton RJ, Aronson WJ, Presti JC Jr, Terris MK, Kane CJ, Amling CL, Freedland SJ. 2007. Race, biochemical disease recurrence, and prostate-specific antigen doubling time after radical prostatectomy: Results from the SEARCH database. Cancer 110: 2202-2209.

Han Y, Signorello LB, Strom SS, Kittles RA, Rybicki BA, Stanford JL, Goodman PJ, Berndt SI, Carpten J, Casey G, et al. 2015. Generalizability of established prostate cancer risk variants in men of African ancestry. Int J Cancer 136: 1210-1217.

Han Y, Rand KA, Hazelett DJ, Ingles SA, Kittles RA, Strom SS, Rybicki BA, Nemesure B, Isaacs WB, Stanford JL, et al. 2016. Prostate cancer susceptibility in men of African ancestry at 8q24. J Natl Cancer Inst 108: djv431.

Hjelmborg JB, Scheike T, Holst K, Skytthe A, Penney KL, Graff RE, Pukkala E, Christensen K, Adami HO, Holm NV, et al. 2014. The heritability of prostate cancer in the Nordic Twin Study of Cancer. Cancer Epidemiol Biomarkers Prev 23: 2303-2310.

Hooker S, Hernandez W, Chen H, Robbins C, Torres JB, Ahaghotu C, Carpten J, Kittles RA. 2010. Replication of prostate cancer risk loci on $8 \mathrm{q} 24,11 \mathrm{q} 13,17 \mathrm{q} 12,19 \mathrm{q} 33$, and Xp11 in African Americans. Prostate 70: 270-275.

Hsing AW, Yeboah E, Biritwum R, Tettey Y, De Marzo AM, Adjei A, Netto GJ, Yu K, Li Y, Chokkalingam AP, et al. 2014. High prevalence of screen detected prostate cancer in West Africans: Implications for racial disparity of prostate cancer. J Urol 192: 730-735.

Hudson MA, Luo S, Chrusciel T, Yan Y, Grubb RL III, Carson K, Scherrer JF. 2014. Do racial disparities exist in the use of prostate cancer screening and detection tools in veterans? Urol Oncol 32: 34.e9-18

Jayadevappa R, Chhatre S, Johnson JC, Malkowicz SB. 2011a. Variation in quality of care among older men with localized prostate cancer. Cancer 117: 2520-2529.

Jayadevappa R, Chhare S, Johnson JC, Malkowicz SB. 2011b. Association between ethnicity and prostate cancer outcomes across hospital and surgeon volume groups. Health Policy 99: 97-106.

Kane CJ, Im R, Amling CL, Presti JC Jr, Aronson WJ, Terris MK, Freedland SJ; SEARCH Database Study Group. 2010. Outcomes after radical prostatectomy among men
Prostate Cancer Disparities by Race and Ethnicity

who are candidates for active surveillance: Results from the SEARCH database. Urology 76: 695-700.

Khani F, Mosquera JM, Park K, Blattner M, O'Reilly C, MacDonald TY, Chen Z, Srivastava A, Tewari AK, Barbieri CE, et al. 2014. Evidence for molecular differences in prostate cancer between African American and Caucasian men. Clin Cancer Res 20: 4925-4934.

Kim T, Cui R, Jeon YJ, Lee JH, Lee JH, Sim H, Park JK, Fadda P, Tili E, Nakanishi H, et al. 2014. Long-range interaction and correlation between $M Y C$ enhancer and oncogenic long noncoding RNA CARLo-5. Proc Natl Acad Sci 111: 4173-4178.

Knipe DW, Evans DM, Kemp JP, Eeles R, Easton DF, KoteJarai Z, Al Olama AA, Benlloch S, Donovan JL, Hamdy FC, et al. 2014. Genetic variation in prostate-specific antigen-detected prostate cancer and the effect of control selection on genetic association studies. Cancer Epidemiol Biomarkers Prev 23: 1356-1365.

Kote-Jarai Z, Olama AA, Giles GG, Severi G, Schleutker J, Weischer M, Campa D, Riboli E, Key T, Gronberg H, et al. 2011. Seven prostate cancer susceptibility loci identified by a multi-stage genome-wide association study. $\mathrm{Nat} \mathrm{Ge}$ net 43: 785-791.

Koutros S, Berndt SI, Hughes Barry K, Andreotti G, Hoppin JA, Sandler DP, Yeager M, Burdett LA, Yuenger J, Alavanja $M C$, et al. 2013. Genetic susceptibility loci, pesticide exposure and prostate cancer risk. PLoS ONE 8: e58195.

Lange EM, Johnson AM, Wang Y, Zuhlke KA, Lu Y, Ribado JV, Keele GR, Li J, Duan Q, Li G, et al. 2014. Genomewide association scan for variants associated with earlyonset prostate cancer. PLoS ONE 9: e93436.

Ledet EM, Sartor O, Rayford W, Bailey-Wilson JE, Mandal DM. 2012. Suggestive evidence of linkage identified at chromosomes 12q24 and 2p16 in African American prostate cancer families from Louisiana. Prostate 72: 938-947.

Lee WH, Morton RA, Epstein JI, Brooks JD, Campbell PA, Bova GS, Hsieh WS, Isaacs WB, Nelson WG. 1994. Cytidine methylation of regulatory sequences near the $\pi$-class glutathione $S$-transferase gene accompanies human prostatic carcinogenesis. Proc Natl Acad Sci 91: 11733-11737.

Li R, Wheeler T, Dai H, Frolov A, Thompson T, Ayala G. 2004. High level of androgen receptor is associated with aggressive clinicopathologic features and decreased biochemical recurrence-free survival in prostate: Cancer patients treated with radical prostatectomy. Am J Surg Pathol 28: 928-934.

Lichtenstein P, Holm NV, Verkasalo PK, Iliadou A, Kaprio J, Koskenvuo M, Pukkala E, Skytthe A, Hemminki K. 2000. Environmental and heritable factors in the causation of cancer-Analyses of cohorts of twins from Sweden, Denmark, and Finland. N Engl J Med 343: 78-85.

Liss MA, Billimek J, Osann K, Cho J, Moskowitz R, Kaplan A, Szabo RJ, Kaplan SH, Greenfield S, Dash A. 2013. Consideration of comorbidity in risk stratification prior to prostate biopsy. Cancer 119: 2413-2418.

Litwin MS, Greenfield S, Elkin EP, Lubeck DP, Broering JM, Kaplan SH. 2007. Assessment of prognosis with the total illness burden index for prostate cancer: Aiding clinicians in treatment choice. Cancer 109: 1777-1783.

Lose F, Batra J, O'Mara T, Fahey P, Marquart L, Eeles RA, Easton DF, Al Olama AA, Kote-Jarai Z, Guy M, et al. 2013. Common variation in Kallikrein genes KLK5, 
T.R. Rebbeck

KLK6, KLK12, and KLK13 and risk of prostate cancer and tumor aggressiveness. Urol Oncol 31: 635-643.

Lyratzopoulos G, Barbiere JM, Greenberg DC, Wright KA, Neal DE. 2010. Population based time trends and socioeconomic variation in use of radiotherapy and radical surgery for prostate cancer in a UK region: Continuous survey. BMJ 340: c1928.

Magi-Galluzzi C, Tsusuki T, Elson P, Simmerman K, LaFargue C, Esgueva R, Klein E, Rubin MA, Zhou M. 2011. TMPRSS2-ERG gene fusion prevalence and class are significantly different in prostate cancer of Caucasian, African-American and Japanese patients. Prostate 71: 489-497.

Matsui H, Suzuki K, Ohtake N, Nakata S, Takeuchi T, Yamanaka H, Inoue I. 2004. Genomewide linkage analysis of familial prostate cancer in the Japanese population. $J$ Hum Genet 49: 9-15.

Messer L, Laraia BA, Kaufman JS, Eyster J, Holzman C, Culhane J, Elo I, Burke JG, O’Campo P. 2006. The development of a standardized neighborhood deprivation index. J Urban Health 83: 1041-1062.

Mucci LA, Hjelmborg JB, Harris JR, Czene K, Havelick DJ, Scheike T, Graff RE, Holst K, Möller S, Unger RH, et al. 2016. Familial risk and heritability of cancer among twins in Nordic countries. JAMA 315: 68-76.

Naylor SL. 2007. SNPs associated with prostate cancer risk and prognosis. Front Biosci 12: 4111-4131.

Neslund-Dudas C, Levin AM, Beebe-Dimmer JL, Bock CH, Nock NL, Rundle A, Jankowski M, Krajenta R, Dou QP, Mitra B, et al. 2014. Gene-environment interactions between JAZF1 and occupational and household lead exposure in prostate cancer among African American men. Cancer Causes Control 25: 869-879.

Netto GJ. 2013. Clinical applications of recent molecular advances in urologic malignancies: No longer chasing a "mirage"? Adv Anat Pathol 20: 175-203.

Neuhausen SL, Farnham JM, Kort E, Tavtigian SV, Skolnick MH, Cannon-Albright LA. 1999. Prostate cancer susceptibility locus HPC1 in Utah high-risk pedigrees. Hum Mol Genet 8: 2437-2442.

Parra EJ, Kittles RA, Argyropoulos G, Pfaff CL, Hiester K, Bonilla C, Sylvester N, Parrish-Gause D, Garvey WT, Jin L, et al. 2001. Ancestral proportions and admixture dynamics in geographically defined African Americans living in South Carolina. Am J Phys Anthropol 114: 18-29.

Paskett ED. 2016. The new vital sign: Where do you live? Cancer Epidemiol Biomarkers Prev 25: 581-582.

Perner S, Hofer MD, Kim R, Shah RB, Li H, Möller P, Hautmann RE, Gschwend JE, Kuefer R, Rubin MA. 2007a. Prostate-specific membrane antigen expression as a predictor of prostate cancer progression. Hum Pathol 38: 696-701.

Perner S, Mosquera JM, Demichelis F, Hofer MD, Paris PL, Simko J, Collins C, Bismar TA, Chinnaiyan AM, De Marzo AM, et al. 2007b. TMPRSS2-ERG fusion prostate cancer: An early molecular event associated with invasion. Am J Surg Pathol 31: 882-888.

Pettersson A, Graff RE, Bauer SR, Pitt MJ, Lis RT, Stack EC Martin NE, Kunz L, Penney KL, Ligon AH, et al. 2012. The TMPRSS2:ERG rearrangement, $E R G$ expression, and prostate cancer prostate cancer outcomes: A cohort study and meta-analysis. Cancer Epidemiol Biomarkers Prev 21: 1497-1509.

Pettersson A, Lis RT, Meisner A, Flavin R, Stack EC, Fiorentino M, Finn S, Graff RE, Penney KL, Rider JR, et al. 2013. Modification of the association between obesity and lethal prostate cancer by TMPRSS2:ERG. J Natl Cancer Inst 105: 1881-1890.

Powell I. 2007. Race, biochemical disease recurrence, and prostate-specific antigen doubling time in the SEARCH database. Cancer 110: 2153-2154.

Powell IJ, Banerjee M, Bianco FJ, Wood DP Jr, Dey J, Lai Z, Heath M, Pontes EJ. 2004. The effect of race/ethnicity on prostate cancer treatment outcome is conditional: A review of Wayne State University data. J Urol 171: 15081512.

Rebbeck TR, Haas GP. 2014. Temporal trends and racial disparities in global prostate cancer prevalence. Can J Urol 21: 7496-7506.

Rebbeck TR, Sankar P. 2005. Ethnicity, ancestry, and race in molecular epidemiologic research. Cancer Epidemiol Biomarkers Prev 14: 2467-2471.

Rebbeck TR, Halbert CH, Sankar P. 2006. Genetics, epidemiology, and cancer disparities: Is it black and white? J Clin Oncol 24: 2164-2169.

Reich DE, Cargill M, Bolk S, Ireland J, Sabeti PC, Richter DJ, Lavery T, Kouyoumjian R, Farhadian SF, Ward R, et al 2001. Linkage disequilibrium in the human genome. $\mathrm{Na}$ ture 411: 199-204.

Richie JP, Catalona WJ, Ahmann FR, Hudson MA, Scardino PT, Flanigan RC, deKernion JB, Ratliff TL, Kavoussi LR, Dalkin BL, et al. 1993. Effect of patient age on early detection of prostate cancer with serum prostate-specific antigen and digital rectal examination. Urology 42: 365 374.

Robert SA, Reither EN. 2004. A multilevel analysis of race, community disadvantage, and body mass index among adults in the US. Soc Sci Med 59: 2421-2434.

Robert SA, Strombom I, Trentham-Dietz A, Hampton JM, McElroy JA, Newcomb PA, Remington PL. 2004. Socioeconomic risk factors for breast cancer: Distinguishing individual- and community-level effects. Epidemiology 15: $442-450$

Sakr WA, Grignon DJ, Crissman JD, Heilbrun LK, Cassin BJ, Pontes JJ, Haas GP. 1994. High grade prostatic intraepithelial neoplasia (HGPIN) and prostatic adenocarcinoma between the ages of 20-69: An autopsy study of 249 cases. In Vivo 8: 439-443.

Sarfati D. 2012. Review of methods used to measure comorbidity in cancer populations: No gold standard exists. $J$ Clin Epidemiol 65: 924-933.

Schleutker J, Matikainen M, Smith J, Koivisto P, Baffoe-Bonnie A, Kainu T, Gillanders E, Sankila R, Pukkala E, Carpten J, et al. 2000. A genetic epidemiological study of hereditary prostate cancer (HPC) in Finland: Frequent HPCX linkage in families with late-onset disease. Clin Cancer Res 6: 4810-4815.

Schupp CW, Press DJ, Gomez SL. 2014. Immigration factors and prostate cancer survival among Hispanic men in California: Does neighborhood matter? Cancer 120: 1401 1408. 
Smith DS, Bullock AD, Catalona WJ, Hershcman JD. 1996 Racial differences in a prostate cancer screening study. $J$ Urol 156: 1366-1369.

Stefflova K, Dulik MC, Pai AA, Walker AH, Zeigler-Johnson CM, Gueye SM, Schurr TG, Rebbeck TR. 2009. Evaluation of group genetic ancestry of populations from Philadelphia and Dakar in the context of sex-biased admixture in the Americas. PLoS ONE 4: e7842.

Stefflova K, Dulik MC, Barnholtz-Sloan JS, Pai AA, Walker AH, Rebbeck TR. 2011. Dissecting the within-Africa ancestry of populations of African descent in the Americas. PLoS ONE 6: e14495.

Stier DM, Greenfield S, Lubeck DP, Dukes KA, Flanders SC, Henning JM, Weir J, Kaplan SH. 1999. Quantifying comorbidity in a disease-specific cohort: Adaptation of the total illness burden index to prostate cancer. Urology 54: 424-429.

Stoll BA. 2000. Affluence, obesity, and breast cancer. Breast $J$ 6: $146-149$.

Sundi D, Ross AE, Humphreys EB, Han M, Partin AW, Carter HB, Schaeffer EM. 2013. African American men with very low-risk prostate cancer exhibit adverse oncologic outcomes after radical prostatectomy: Should active surveillance still be an option for them? J Clin Oncol 31: 2991-2997.

Teo YY, Small KS, Kwiatkowski DP. 2010. Methodological challenges of genome-wide association analysis in Africa. Nat Rev Genet 11: 149-160.

Thompson IM, Ankerst DP, Chi C, Goodman PJ, Tangen CM, Lucia MS, Feng Z, Parnes HL, Coltman CA Jr. 2006. Assessing prostate cancer risk: Results from the Prostate Cancer Prevention Trial. J Natl Cancer Inst 98: 529-534.

United States Census Bureau. 2007. 2000 Census technical documentation for SF 3. United States Department of Commerce, Washington, DC.

Verhage BA, Aben KK, Witjes JA, Straatman H, Schalken JA, Kiemeney LA. 2004. Site-specific familial aggregation of prostate cancer. Int J Cancer 109: 611-617.

Wandel C, Witte JS, Hall JM, Stein CM, Wood AJ, Wilkinson GR. 2000. CYP3A activity in African American and European American men: Population differences and functional effect of the CYP $3 A 4^{*} 1 B 5^{\prime}$-promoter region polymorphism. Clin Pharmacol Ther 68: 82-91.

Wardle J, Jarvis MJ, Steggles N, Sutton S, Williamson S, Farrimond H, Cartwright M, Simon AE. 2003. Socioeconomic disparities in cancer-risk behaviors in adolescence: Baseline results from the Health and Behaviour in Teenagers Study (HABITS). Prev Med 36: 721-730.
Prostate Cancer Disparities by Race and Ethnicity

Waters KM, Le Marchand L, Kolonel LN, Monroe KR, Stram DO, Henderson BE, Haiman CA. 2009. Generalizability of associations from prostate cancer genome-wide association studies in multiple populations. Cancer Epidemio Biomarkers Prev 18: 1285-1289.

Weinrich MC, Jacobsen SJ, Weinrich SP, Moul JW, Oesterling JE, Jacobson D, Wise R. 1998. Reference ranges for serum prostate-specific antigen in black and white men without cancer. Urology 52: 967-973.

Xu J, Zheng SL, Chang B, Smith JR, Carpten JD, Stine OC, Isaacs SD, Wiley KE, Henning L, Ewing C, et al. 2001. Linkage of prostate cancer susceptibility loci to chromosome 1. Hum Genet 108: 335-345.

Xu J, Kibel AS, Hu JJ, Turner AR, Pruett K, Zheng SL, Sun J, Isaacs SD, Wiley KE, Kim ST, et al. 2009. Prostate cancer risk associated loci in African Americans. Cancer Epidemiol Biomarkers Prev 18: 2145-2149.

Xu J, Lange EM, Lu L, Zheng SL, Wang Z, Thibodeau SN, Cannon-Albright LA, Teerlink CC, Camp NJ, Johnson AM, et al. 2013. HOXB13 is a susceptibility gene for prostate cancer: Results from the International Consortium for Prostate Cancer Genetics (ICPCG). Hum Genet 132: $5-14$.

Yaeger R, Avila-Bront A, Abdul K, Nolan PC, Grann VR, Birchette MG, Choudhry S, Burchard EG, Beckman KB, Gorroochurn P, et al. 2008. Comparing genetic ancestry and self-described race in African Americans born in the United States and in Africa. Cancer Epidemiol Biomarkers Prev 17: 1329-1338.

Yamoah K, Johnson MH, Choeurng V, Faisal FA, Yousefi K, Haddad Z, Ross AE, Alshalafa M, Den R, Lal P, et al. 2015a. Novel biomarker signature that may predict aggressive disease in African American men with prostate cancer. J Clin Oncol 33: 2789-2796.

Yamoah K, Deville C, Vapiwala N, Spangler E, Zeigler-Johnson CM, Malkowicz B, Lee DI, Kattan M, Dicker AP, Rebbeck TR. 2015b. African American men with lowgrade prostate cancer have increased disease recurrence after prostatectomy compared with Caucasian men. Uro Oncol 33: 70.e15-e22.

Yeager M, Orr N, Hayes RB, Jacobs KB, Kraft P, Wacholder S, Minichiello MJ, Fearnhead P, Yu K, Chatterjee N, et al. 2007. Genome-wide association study of prostate cancer identifies a second risk locus at 8q24. Nat Genet 39: 645649.

Ziegler-Johnson CM, Tierney A, Rebbeck TR, Rundle A. 2011. Prostate cancer severity associations with neighborhood deprivation. Prostate Cancer 2011: 846263. 


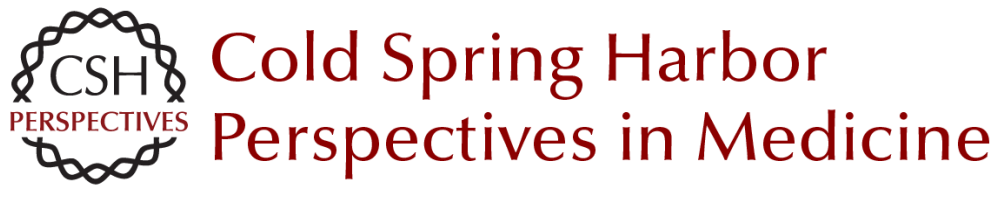

\title{
Prostate Cancer Disparities by Race and Ethnicity: From Nucleotide to Neighborhood
}

\author{
Timothy R. Rebbeck
}

Cold Spring Harb Perspect Med 2018; doi: 10.1101/cshperspect.a030387 originally published online December 11, 2017

\section{Subject Collection Prostate Cancer}

Anatomic and Molecular Imaging in Prostate

Cancer

Eric T. Miller, Amirali Salmasi and Robert E. Reiter

The Epidemiology of Prostate Cancer

Claire H. Pernar, Ericka M. Ebot, Kathryn M. Wilson, et al.

Prostate Stem Cells and Cancer Stem Cells Jia J. Li and Michael M. Shen

Prostate Cancer Epigenetics: From Basic Mechanisms to Clinical Implications Srinivasan Yegnasubramanian, Angelo M. De Marzo and William G. Nelson

The Genomics of Prostate Cancer: A Historic Perspective Mark A. Rubin and Francesca Demichelis

Neuroendocrine Differentiation in Prostate Cancer: Emerging Biology, Models, and Therapies Loredana Puca, Panagiotis J. Vlachostergios and Himisha Beltran

DNA Damage Response in Prostate Cancer Matthew J. Schiewer and Karen E. Knudsen

Transcriptional Regulation in Prostate Cancer David P. Labbé and Myles Brown
New Opportunities for Targeting the Androgen

Receptor in Prostate Cancer Margaret M. Centenera, Luke A. Selth, Esmaeil Ebrahimie, et al.

Prostate Cancer Research at the Crossroads Michael M. Shen and Mark A. Rubin

Immunotherapy for Prostate Cancer Nicholas J. Venturini and Charles G. Drake

Molecular Pathology of High-Grade Prostatic Intraepithelial Neoplasia: Challenges and Opportunities Levent Trabzonlu, Ibrahim Kulac, Qizhi Zheng, et al.

Metastases in Prostate Cancer Federico La Manna, Sofia Karkampouna, Eugenio Zoni, et al.

Genetically Engineered Mouse Models of Prostate Cancer in the Postgenomic Era Juan M. Arriaga and Cory Abate-Shen

Molecular Biomarkers in the Clinical Management of Prostate Cancer Aaron M. Udager and Scott A. Tomlins

Metabolic Vulnerabilities of Prostate Cancer: Diagnostic and Therapeutic Opportunities Giorgia Zadra and Massimo Loda

For additional articles in this collection, see http://perspectivesinmedicine.cshlp.org/cgi/collection/ 